\title{
Editorial
}

\section{We shall Start Health Intervention against Collateral Effect of Pandemic to Metabolic, Cardiovascular and Mental Health in Migrants, Children and Caregivers}

Source: Clinical Social Work and Health Intervention

Volume: 12

Issue: 3

Pages: $6-8$

Cited references: 12

CSWHI 2021; 12(3): 6 - 8; DOI: 10.22359/cswhi_12_3_20 (C) Clinical Social Work and Health Intervention

\section{From the guest Editors}

This current issue of No 3 of Clinical Social work and Health Intervention vol. 12, is the first one after two covid HIV and other pandemic consequences (1), not to ignore collateral effect of those two largest viral epidemics in recent years. The articles focus within a group of German authors the need for emergency health and social worker intervention in catastrophes during pandemics, earthquakes and other special events affecting not only victims but also health care staff (Merkt et al, Fritzsch et al). Zacharova et al (2) discuss collateral effects of migrant and pandemic stress events, on rescue and nursing staff in Germany and Masan et al. on late consequences for mental health as well).

Kiann et al.and Merkt et al. emphasize not to forget dental and diabetes health as drivers of cardiovascular mortality largely ignored within last 2 years (Manoranjan et al. \& Minarik et al.). Four German-Swiss group of authors: Osman et al., Wahl et al. and Changee et al. and Niemuth et al. focus on the important roles of pharmacies especially when first line e.g. general practitioners are overwhelmed with covid 19 (EU USA) or HIV (Sub-Saharan Africa) patients.

Apart from mental dental and cardiovascular health, please we shall not forgot female (mothers) children (families) heavily affected with pandemic related poverty such as in wake-up-call articles submitted and published with groups from Pakistan, Saudi Arabia but also the EU (Wahab el al,, Abdalllahi et al., Minarovicova \& Popovicova et al.) (2). 
We shall not ignore those health care interventions also to pharmacists, dental specialists, MD, rescuers and nurses, because they all have served within last 2 years, with collateral effects of Covid and HIV to mental, cardiovascular, endocrine and dental health which may destroy access to health care to vulnerable groups of women, children, refugees and exhausted health care providers of social rescue health and nursing services worldwide.

\section{Roberto Cauda ${ }^{1}$ Zlata Ondrusova $\mathbf{a}^{2,3}$ Paul Tomanek ${ }^{2,4}$ Maria Hardy ${ }^{4}$}

1. Sacred Heart University Hospital Gemelli, It of tropical and Infections Disease, Rome, Italy

2. Misericordia Dei and st Sarah Inst Zilina, Banská Bystrica St. Elizabeth University and Dept of Tropical Disease, Slovak Medicine University, Bratislava, Slovakia

3. Institute of Health and Social work, SEUC Backi Petrovac, Republic of Serbia

4. Dept of Social work, Mental health Diaconaess programmeArchdiocese of Vienna, Austria

\section{References}

1. WHO ANNUAL REPORTREPORT.2020, World Halth Organisation Geneva, $2021.55 \mathrm{pp}$

2. FRITZSCH T, LULIAK M, WULF G, MARKT PHILIPPE,VOLLMANN WILK, MASAN J, HAMAROVA M, KIANN J, LULIAK M, OSMAN B, CZIRFUSZ A,WAHL S, CHAGEE AS, KALAVSKI E, MANORANJAN LAKSMANN, SYER ASBD WAHAB, ABD RAHIM CHANGES, MONA ABDALLAHI, AYESHA GUL, MINARIK P, DUBOVCOVA M, NIEMUTH R, POPOVICOVA M, BELOVICOVA M, HUDAKOVA T, ZACHAROVA E, MOLTASOVA K, KYASOVA M, ULLAH S, NAZ (2021) Clinical Social Work and Health Intervention no 3.2021 Vol. 12, All above cited articles, appearing in this volume CSW 12.2021, 2-108.
3. GOMBITA P, OLAH M, KOVAC R, JURASEK M, KOSTICOVA M, TAZIAROVA M, ZABAVOVA S, HALUSKOVA E, JACKULIKOVA M, ZEMKO P, KATUNSKA M, ADAMCOVA J, BOZIK J, RAC I, BUNDZELOVA K, PAVLOVICOVA A, MASZLAK W, TONZAR D (2020) Senior homeless population was Covid-19 free in 3 shelter communities after adapting the Life Island model (Note). In: Clinical social work and health intervention, Vol. 11, nr. 3, 2020, ISSN 2076-9741/online ISSN 2222386X/Print, pp. 78-79.

4. MIKOLASOVA G, MLYNARCIK P, BOZIK J, JACKULIKOVA M, PAVLOVICOVA A, OLAH M, KOVAC R, JANCOVIC M, DOKTOROV A, POLONOVA J, ZEMKO P, JURASEK M, ZABAVOVA S, BRYNDZAK P, TAZIAROVA M (2020) Cohortation and testing of elderly homeless within COVID pandemics in an Urban envi- 
ronment. In: Lekarsky obzor, vol. 69, nr. 11, 2020, ISSN 0457-4214, pp.381-382.

5. MASZLAK V, ZEMKO P, HERDICS G, JURASEK M, PAVLOVICOVA A, RADI F, BUNDZELOVA K, KOSTICOVA M, ZABAVOVA S, GOMBITA P, FABIAN A, MATEJOVA A, LACA P, VALACH M, SCHAVEL M, TONZAR D (2020) Zero Covid-19 incidence among two large shelters of homeless population in rural settlement- in march-to july 2020: An important role of partial lockdown. In: Lekarsky obzor, vol. 69, nr. 11, 2020, ISSN 0457-4214, pp.379-380.

6. PALOCKOVA M, CHOVANCOVA S, SUGAROVA D, ZDILOVA E, SASVARY F, SASVARY M, BARKASI D, GULASOVA M, KMIT I, OLAH M, HOCHMAN R, HALUSKOVA E, PARTELOVA M, TRICHARD E (2021) Covid-19 has only temporarily interrupted social and health services in rural Albania in 2020. In: Clinical social work and health intervention, Vol.12, Nr. 1, 2021, ISSN 2076-9741/online ISSN 2222386X/Print, pp. 17-19.

7. KIMULI D, BENCA J, NAMULANDA V, OKOTH V, UTESENA M, TAZIAROVA M, KMIT I, PALOCKOVA D, ADAMOVA I, KALAVSKA Z, KOMLOSI M Z, HUPKOVA I, SUVADA J, MAMOVA A, MOLNAROVA K, MIKOLASOVA G, HAJDEN Z, KUNIAKOVA M, PAGAC P, PAUER K, SECKOVA S, KAFKOVA J, JANCOVIC M, SLADECKOVA V, KALAVSKA A, SHAHUM A, KONOSOVA H, HORVATHOVA E, RADKOVA L, BUCKO L, SRAMKOVA M, VALLUSOVA L, LIBOVA L, OTRUBOVA J, MURGOVA A, DRGOVA J, BARTKOVJAK M, WACHIRA M AND MULAMA C (2020) To bring children from street to school - 20 years experience of educational/nutrition/healthcare programme focused on streetchildren and orphans in Burundi, Rwanda, Kenya, Sudan, Ethiopia, Uganda, Lesotho, Chad, Madagascar and Mozambique. In: Lekarsky obzor, Vol. 69, Issue 5, 2020, ISSN 0457-4214, pp.157-159.

8. NADDOUR A, TRILISINSKAYA I, KOZON V, HEIDER P, CZARNECKI P, KONOSOVA H, JALILI N, DUBOVCOVA M, BOSNAKOVA M, GIERTLIOVA D, GALLOVA A, PAUER K, UTESENA M,
HUNADYOVA S, JACKULIKOVA M, HUNAKOVA LAND SIMONEK T (2020) Scabies is the commonest skin/soft tissue infection (SSTI) in refugee children and adults escaping war from Middle East via Turkish and Ukrainian border. In: Lekarsky obzor, Vol. 69, Issue 5, 2020, ISSN 0457-4214, pp.170172.

9. PANDYA L, PHOHLA L, BUCKO L, PALENIKOVA M, HALCINOVA M, MIKLOSKOVA M, KONOSOVA H, LIBOVA L, OTRUBOVA J, MURGOVA A, CERVENKOVA M, PAUE K, HUNYADYOVA S AND BIBZA M (2020) Antimalnutrition program in low - cost children in rural regions in Karnataka state India and in Mandalay province, Myanmar In: Lekarsky obzor, Vol. 69, Issue 5, 2020, ISSN 04574214, pp.162-164

10. SHAHMAN A, HAEL H, SUVADA J, ULMAN S P, JALILI N AND TOPOLSKA A (2020) Antimalnutrition Projects for children and mothers in areas of armed conflict in Yemen and Autonomous Region - Kurdistan, Iraq. In: Lekársky obzor, Vol. 69, Issue 5, 2020, ISSN 0457-4214, pp.147-148.

11. SAOSETHA V, UTESENA M, SECKOVA S, KUBALIKOVA Z, BENCA J, SLADECKOVA V, BUCKO L, SHAHUM A, VICHET K, VLCEK R, OLAH M, HOIN L (2021) Educational social and health joint bicoloral world \& SEU program for HIV positive Cambodian children - Research note. In: Clinical social work and health intervention, Vol.12, Nr. 1, 2021, ISSN 2076-9741/online ISSN 2222-386X/Print, pp. 23-25.

12. MIKOLASOVA G, NADDOUR A, SIMONEK T, BAKOS M, BUJDOVA N, KONOSOVA H, HEIDER P, CZARNECKI P, PAUER K, BIELOVA M, BYDZOVSKY J, JACKULIKOVA M, TRILISINSKAYA I, HUNADYOVA S, MRAZOVA M, HAJ ALI P, SUBRAMANINAN S, BENCA G (2020) Absence of outbreaks of gastroentities in UNHCR refugee camp in children. In: Lekarsky obzor, Vol. 69, Issue 5, 2020, ISSN 0457-4214, pp.168-169 